Relations industrielles

Industrial Relations

\title{
Experience Rating, Work Injuries and Benefit Costs
}

Some New Evidence

\section{La tarification par incidence, les accidents du travail et le coût des prestations}

\author{
Quelques données récentes
}

\section{Valoración de la experiencia, accidentes de trabajo y costo de beneficios}

\section{Algunas nuevas evidencias}

\author{
Michele Campolieti, Douglas Hyatt et Terry Thomason
}

Volume 61, numéro 1, hiver 2006

URI : https://id.erudit.org/iderudit/013723ar

DOI : https://doi.org/10.7202/013723ar

Aller au sommaire du numéro

Éditeur(s)

Département des relations industrielles de l'Université Laval

ISSN

0034-379X (imprimé)

1703-8138 (numérique)

Découvrir la revue

Citer cet article

Campolieti, M., Hyatt, D. \& Thomason, T. (2006). Experience Rating, Work Injuries and Benefit Costs: Some New Evidence. Relations industrielles / Industrial Relations, 61(1), 118-145. https://doi.org/10.7202/013723ar

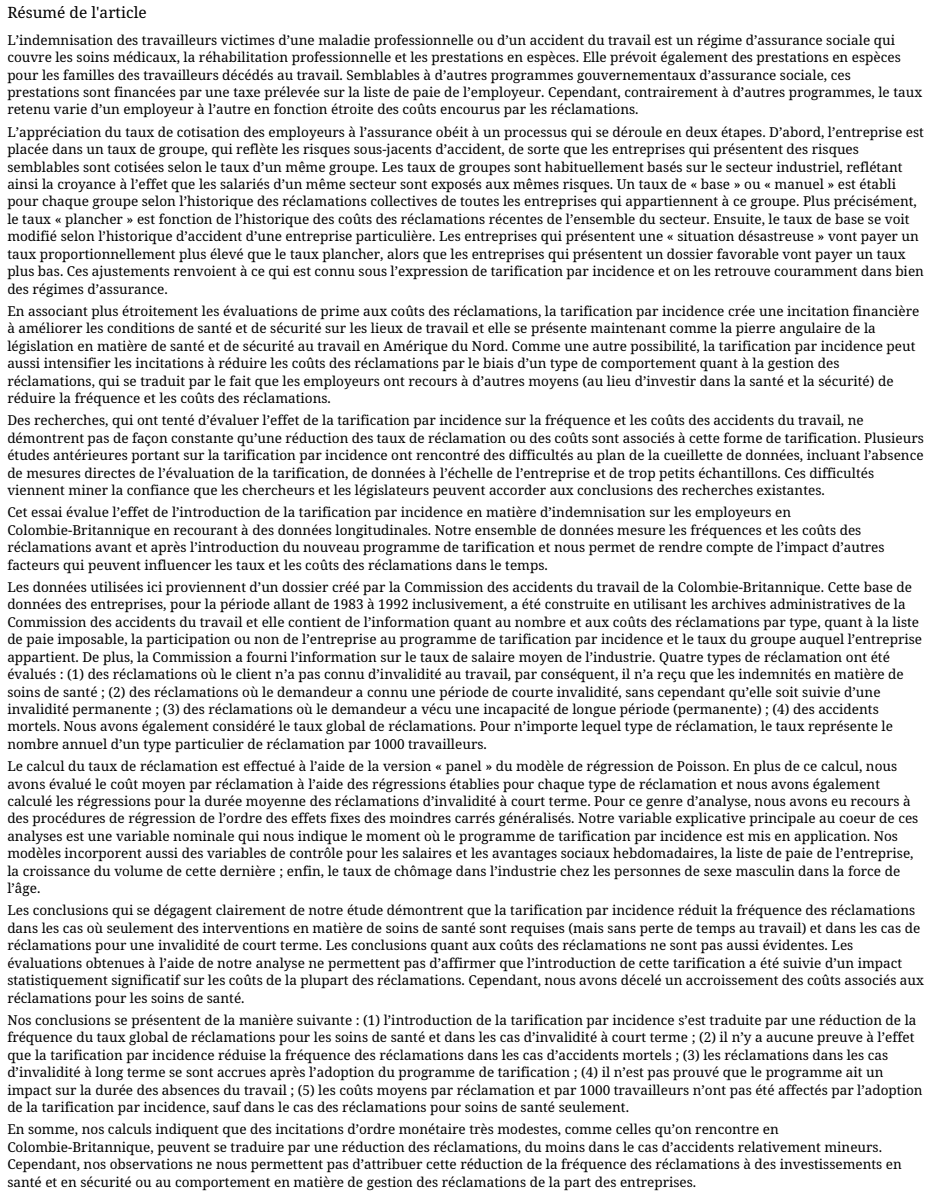

Tous droits réservés (C Département des relations industrielles de l'Universite Laval, 2006
Ce document est protégé par la loi sur le droit d'auteur. L'utilisation des services d'Érudit (y compris la reproduction) est assujettie à sa politique d'utilisation que vous pouvez consulter en ligne.

https://apropos.erudit.org/fr/usagers/politique-dutilisation/ 


\title{
Experience Rating, Work Injuries and Benefit Costs \\ Some New Evidence
}

\author{
Michele Campolieti \\ Douglas HyatT \\ TERRY THOMASON
}

In 1986, British Columbia's Workers' Compensation Board introduced an experience rating program that provided a modest financial incentive for employers to reduce the costs of claims. Using a comprehensive panel data set, we find that claims frequency for health care only and short-term disability claims was reduced following the introduction of experience rating. The introduction of the program did not affect costs for most claim types, except for health care only claims.

Workers' compensation is a social insurance program that provides for medical treatment, vocational rehabilitation and cash benefits to workers who have been harmed as the result of an occupational illness or injury, and provides cash benefits for the families of workers killed on the job. Akin to other government-mandated social insurance programs, these benefits are financed by an employer payroll tax. Unlike most other programs, however, the rate charged varies across employers as a direct function of incurred claims costs.

- Campolieti, M., Department of Management, Scarborough Campus, and Centre for Industrial Relations, University of Toronto, Toronto, Ontario, campolie@ chass.utoronto. ca.

- HyatT, D., Rotman School of Management and Centre for Industrial Relations, University of Toronto, Toronto, Ontario, doug.hyatt@utoronto.ca.

- Thomason, T. (deceased), Charles T. Schmidt, Jr. Labor Research Center, University of Rhode Island.

- The research support of SSHRC and the Connaught Fund at the University of Toronto is greatly appreciated. Please address correspondence to Michele Campolieti. 
An employer's workers' compensation assessment rate is determined through a two-stage process. In the first stage, the firm is placed in a rate group, which reflects underlying injury risks, so that firms with similar risk profiles are placed into the same rate group. Rate groups are generally based on an industrial sector, reflecting the belief that employees in the same sector are exposed to similar risks. A "base" or "manual" rate is established for each rate group determined by the collective claims experience of all firms in the group. Specifically, the base rate is a function of the entire sector's recent claims cost history. In the second stage, the base rate is further modified according to the individual firm's own accident experience. Firms with "adverse experience" pay a rate that is proportionately higher than the base rate, while firms with more favourable experience pay a lower rate. These adjustments are referred to as experience rating and are common in many insurance plans.

By more closely linking assessments to claims costs, experience rating creates a financial incentive to improve workplace health and safety conditions and has become a cornerstone of occupational health and safety policy in North America. Alternatively, experience rating can also increase the incentives to reduce claim costs through some sort of claims management behaviour, in which employers use other means to reduce claims rates and costs.

Studies that have sought to measure the impact of experience rating on the incidence and costs of work injuries do not consistently find a reduction in claims rates or costs associated with experience rating. As we will describe, many of the previous studies of experience rating have suffered from data limitations including a lack of direct measures of experience rating, lack of firm-level data, and small sample sizes, all of which circumscribe the confidence that researchers and policy makers can place on the findings in existing research.

We examine the impact of the introduction of workers' compensation experience rating on a panel of employers in British Columbia (BC), Canada. Our data set provides measures of claim frequencies and costs before and after experience rating and permits us to control for a number of other factors that could affect these outcomes over time. We find evidence that experience rating leads to a reduction in the frequency of short-term disability and health care only claims. In addition, we also find that the introduction of the experience rating program was not associated, for the most part, with an increase in average cost per claim. Our estimates also indicate that the decrease in the claims rate did not offset the increase in claim costs for health care costs, which results in an increase in expected claim costs per 1,000 workers. 
In the next section we summarize previous studies examining the impact of experience rating on workers' compensation claims activity. We then outline the relevant institutional features of the Workers' Compensation Board of British Columbia's Experience Rated Assessment plan. In the fourth section, we describe our data and approaches for estimating the impact of experience rating on the frequencies and costs of health care only, short-term disability, long-term disability and fatal claims. Estimation results are reported in the next section. The paper concludes with some summary observations.

\section{EXPERIENCE RATING IN WORKERS' COMPENSATION}

Under strict assumptions, - perfect competition in product and factor markets, wage premia for risk that fully reflect the costs of work-related injury and disease, and the absence of a market that allows workers to purchase their own disability insurance-perfect experience rating is predicted to have no additional impact on improving health and safety beyond that induced by compensating wage differentials for risks that arise in the labour market. The compensating wage differential fully indemnifies workers for work-related health risks and reduces the competitiveness of relatively high risk firms. Indeed, if something less than perfect experience rating was introduced, such that relatively high-risk employers could pass on some of the costs of injury to safer employers, employers may reduce their injury prevention investments, with concomitant implications for health and safety.

Assuming, however, that wage differentials for risk are not fully compensating, economic theory predicts that experience rating should induce employer investments in accident prevention, thereby reducing the number and costs of injuries (Ruser, 1985). Accordingly, most studies of experience rating have sought to measure the extent to which the frequency of claims or the severity of injuries (usually measured as the duration of absence from work or the cost of a claim) respond to changes in the magnitudes of the financial incentive. An alternative effect of experience rating programs is that they provide incentives to reduce claim costs by discouraging claims by other means (Thomason and Pozzebon, 2002).

Existing research (including Russell, 1974; Chelius and Smith, 1983; Ruser, 1985, 1991, 1993; Harrington, 1988; Worrall and Butler, 1988; Moore and Viscusi, 1989), generally finds support for the hypothesis of a salutary impact of experience rating on claim frequency. However, some of these studies use cross-sectional data and also lack direct measures of 
the degree of experience rating. As a result, investigators have been forced to rely on proxies related to firm size since generally, in the United States, the magnitude of the experience rating incentive is positively related to firm size. However, it is possible that workplace safety and firm size are related for reasons other than experience rating. If, for example, there are economies of scale in the provision of safety, then it may be expected that large firms will have lower claim rates than small firms, even in the absence of experience rating. For example, using longitudinal firm level data, Ruser $(1985,1991,1993)$ found that claim rates decrease as the size of the firm increases.

A handful of longitudinal studies have taken advantage of "natural experiments" to compare claim rates before and after the introduction of experience rating. While generally supporting the hypothesis that experience rating results in a reduction in the claims rate, these studies are problematic because they utilize highly aggregated state/provincial-level data as well as industry level data (Bruce and Atkins, 1993; Durbin and Butler, 1998) or data from an extremely small number of employers (Chelius and Kavanaugh, 1988). In general, the design of the "experiment" in studies using aggregate data will consist of "before" and "after" comparisons in the pre- and post-intervention outcome measure of interest.

Research examining the relationship between experience rating and injury severity has produced results that are less definitive than the claims rate studies. Some have found a statistically significant negative relationship between experience rating and various measures of injury severity, including compensation costs (Butler and Worrall, 1988), and the average duration of disability (Chelius and Kavanaugh, 1988). However, most researchers have obtained mixed results, including studies by Krueger (1990) and Kralj (1995), who examined the relationship between experience rating and claim duration, Thomason (1993), who estimated regressions predicting the probability of permanent disability, and Ruser (1993), who investigated the incidence of claims classified by severity. In addition, the severity studies suffer from methodological problems similar to those that plague the claims rate research. In general, the research examining the relationship between experience rating and injury severity has produced mixed results. Reviews of the evidence have determined that, "from the existing body of research, we cannot conclude that workers' compensation premiums provide effective incentives to reduce workplace hazards" (Boden, 1995: 287) and "[b]ecause the workers' compensation system provides generalized, financial incentives, the failure to clearly associate declines in risk with increases in injury costs is disappointing" (Smith, 1992: 581). 


\section{EXPERIENCE RATING IN BRITISH COLUMBIA}

The data for this study come from the province of British Columbia, Canada. In this section we describe the salient features of the workers' compensation system in British Columbia, with particular emphasis on the nature and magnitudes of the financial incentives created by its experience rating initiative.

The workers' compensation program in British Columbia is exclusively administered by a provincial agency, the Workers' Compensation Board (WCB). The WCB provides injured workers with cash benefits, medical and vocational rehabilitation services. Cash benefits are paid to workers who have suffered a work disability resulting from a workplace injury or illness and to the families of workers who were killed in industrial accidents. Disabled workers may receive short- or long-term disability benefits. Short-term (STD) benefits are paid to claimants beginning the day after injury up until the point at which their medical condition has stabilized, or the worker returns to work, whichever comes first. Weekly STD benefits are equal to 75 percent of the claimant's pre-injury weekly wage (gross of taxes). Long-term (LTD) benefits to claimants who have suffered a permanent consequence, such as an amputated limb, are paid in one of two forms: a lifetime pension based on a "meat" chart or wage loss benefits (75 percent of pre-injury earnings) until age $65 .{ }^{1}$ The claimant would receive whichever of the two alternatives was larger. In addition, STD benefits are also subject to maximum and minimum payments, so that the actual replacement rate for earnings may differ from the statutory replacement rate for some workers.

Benefits are financed by employer assessments that are equal to the product of the firm's assessable payroll and the applicable assessment rate. ${ }^{2}$ In 1986, the Workers' Compensation Board of British Columbia introduced a new experience rating regime, called the Experience Rated Assessment plan (ERA). Before 1986, experience rating was limited to employers in the logging, construction, forest products, and metal mining industries. Other firms were not experience rated. In contrast, ERA applied to all

1. The value of benefits has changed since the end of our study period.

2. The assessment rate is expressed as the number of dollars in premiums per hundred dollars of assessable payroll. Employee salaries are assessable up to a maximum wage, which in 1992 was equal to $\$ 48,000$ per annum. It should be noted that in the U.S., rates are adjusted by a number of additional factors, including modifications for firm size, premium discounts, schedule rating, dividends and other factors outlined in Thomason, Schmidle and Burton (2001, Appendix C). 
compulsory rated firms, regardless of size or industry. ${ }^{3}$ The ERA plan in British Columbia differs from those in other Canadian provinces, which often exclude small employers and may also have different experience rating programs for different industries, since it applies to all industries and employers.

Implementation of ERA was staggered so that the plan was first applied, in 1986, to most of the firms in previously experience-rated industries as well as to heavy manufacturing and trucking industries. With the exception of farming, ERA was introduced to all other firms beginning in 1987. Farming was introduced to ERA in 1988. Finally, firm premiums in the ERA plan are fully or partially adjusted depending on industry and assessable payroll (or the number of years that the firm has been registered with the WCB). Farms participate at the 25 percent level. Firms other than farming operations participate at the 50 percent level if they have one year or less of assessable payroll or if total assessable payroll over the past two years is less than the total of two times the maximum assessable wage rate. All other firms participate at the 100 percent level.

ERA adjusts base manual rates according to the following formula:

$$
\mathrm{R}=\mathrm{B} \times\left[1+\left(\mathrm{L}^{*} \mathrm{E}\right)\right]
$$

where $\mathrm{R}$ is the ERA-adjusted rate, $\mathrm{B}$ is the base rate, $\mathrm{L}$ is the participation level (equal to $1,0.5$, or 0.25 ), and $\mathrm{E}$ is the adjustment factor, also known as the firm variance, which is equal to:

$$
\mathrm{E}=\left(\mathrm{R}_{\mathrm{f}}-\mathrm{R}_{\mathrm{s}}\right) / \mathrm{R}_{\mathrm{s}}
$$

where $R_{f}$ is the firm ratio, defined as the ratio of firm claim costs to firm payroll and $R_{s}$ is the industry ratio, defined as the ratio of industry claim costs to industry payroll. Claim cost and payroll data are calculated annually, based on claims that were initiated during the two previous years. Importantly, claim costs are limited to those paid within a 30-month "review period"; that is, all costs paid during the two previous years up until June 30 of the third year. ${ }^{4}$ These costs include the capitalized value of any permanent

3. The Workers' Compensation Act of British Columbia distinguishes firms for whom coverage is required and those for whom coverage is voluntary or noncompulsory. Over the period relevant to our data, noncompulsory firms included banks, insurance companies, and law, accounting, medical and dental offices.

4. Other experience rating programs in Canada vary the length of assessment period. With the exception of Manitoba, which only uses the previous year, most plans use claim costs from the previous three years. Generally speaking, the plans in the provinces of Alberta, Nova Scotia, New Brunswick, Newfoundland and Prince Edward Island are fairly similar in structure to the ERA program. However, the ERA plan in BC applies to all employers, while the plans in other provinces tend to exclude small firms (Workers' Compensation Board of British Columbia, 1997). 
disability pensions awarded during this period, but not if the permanent disability pension is awarded after the period. An administrative inventory (Hunt, 1992: 46) that considered the ERA formula noted:

This means that long duration claims will not count against an employer's ERA merit/demerit beyond the two-and-one-half-year maximum period. It also means that if inefficient claims adjudication, slow medical recovery, or employer stalling with appeal procedures delays the award of a pension beyond the two-and-one-half year period from the date of injury, this amount will not count against the employer's experience rating evaluation.

The ERA program sets the maximum adjustment factor, E, to between plus and minus 33 percent. ${ }^{5}$ This indicates that firm accident experience may affect the assessment rate by as much as two-thirds of the base rate. For example, if the base rate is $\$ 3.00$ per $\$ 100$ of payroll, then an employer may pay as little as $\$ 2.00$ or as much as $\$ 4.00$ per $\$ 100$ of payroll, based on their own accident experience. Compared to experience rating plans in the United States where it is possible for a firm to be "self-rated" so that there is, essentially, a one-to-one relationship between benefit payments and compensation costs, ERA has a limited "bite". On the other hand, unlike the U.S. experience rating program, ERA applies to firms of all sizes.

\section{METHODOLOGY AND DATA}

The data used in the analyses that follow were drawn from a file created by the Workers' Compensation Board of British Columbia. This database of firms, from 1983 to 1992 inclusive, was compiled from the administrative records of the WCB and contains information regarding the number and cost of claims by type, firm assessable payroll, whether the firm participated in ERA, and the rate group to which the firm belongs. In addition, the WCB added information on the industry average wage rate. For the purposes of our analysis, we limited the data to firms which had not been experiencerated prior to the introduction of ERA and which had employed five or more persons each year during the reference period, yielding a final data set of 4,293 firms. ${ }^{6}$

Four types of claim rates are examined: (1) claims where the claimant did not experience work disability and, therefore, only received health

5. Prior to ERA, the experience rating program that covered firms in the logging, construction, forestry and metal work groups allowed for more modest merit and demerit adjustments. In particular, the merits and demerits, depending on the industry, ranged from 30 to 39 percent. However, the inclusion window varied from 3 to 7 years, depending on the industry.

6. Only 412 of these firms entered the ERA program in 1986, the rest entered in 1987. 
care benefits (HCO); (2) claims where the claimant experienced short-term disability (STD), but suffered no permanent consequence; (3) claims where the claimant experienced long-term (i.e., permanent) disability (LTD); and, (4) fatalities. We also studied the total claims rate. For any claim type, the claims rate represents the annual number of that particular type of claim per 1,000 workers.

Because we observe information on multiple firms over a number of years, we estimate a panel data version of a Poisson regression model:

$$
\begin{aligned}
& \operatorname{prob}\left(\mathrm{Y}=\mathrm{y}_{\mathrm{it}}\right)=\frac{\exp \left(-\lambda_{i t}\right) \lambda_{i t}{ }_{i t}}{y_{i t} !} \\
& \lambda_{i t}=x_{i t}^{\prime} \beta+\gamma P_{i t}+\alpha_{i t},
\end{aligned}
$$

where $\mathrm{y}_{i t}$ is the number of compensation claims experienced by the $i^{\text {th }}$ firm during the $t^{\text {th }}$ year, $\mathrm{P}_{i t}$ is a dummy variable indicating whether the $i^{\text {th }}$ firm participated in the ERA program during the $t^{\text {th }}$ year, and $\mathrm{x}_{i t}$ is a vector of explanatory variables. The term denotes an industry specific fixed effect.

Our key independent variable, participation $\left(P_{\mathrm{it}}\right)$, takes the value one if the firm participated in the ERA program, and zero otherwise. Because the overwhelming majority of firms in our sample participate in ERA at the 100 percent level, we are unable to exploit variation in the participation level as an additional route for examining the impact of ERA.

Weekly benefits may affect both firm and worker behaviour. Holding other factors constant, higher weekly benefits would increase claims by workers and should produce a positive sign on this control. On the other hand, higher benefit levels also encourage employers to take greater precautions and to invest in health and safety. Alternatively, employers may also challenge some claims or also discourage workers from filing claims by providing light duties or other special work arrangements (Thomason and Pozzebon, 2002). These behaviours would tend to suggest a negative sign on the benefit variable. As a result, the $a$ priori effect of benefits is indeterminate. However, most empirical evidence suggests that the effects on worker behaviour dominate.

Expected weekly benefits were based on the estimated average firm wage. This variable was calculated using the limit factor method, an actuarial technique used by the National Council of Compensation Insurers. ${ }^{7} \mathrm{We}$ controlled for the effects of benefits in our empirical models by including the level of benefits and its square. The benefits squared term is included to capture any nonlinearities in the relationship between benefits and claim

7. This method require a wage distribution, which we obtained using data from the 1988-90 Labour Market Activity Survey conducted by Statistics Canada. 
rates. This sort of specification has been frequently used in the literature (e.g., among others, Ruser, 1991, 1993).

Another factor that can affect claims is the average wage paid by the firm. If wages are a measure of the worker's opportunity cost of disability, this variable should be negatively related to the claims rate and costs. However, the wage variable may also be positively related to injuries since workers require compensating differentials to undertake more hazardous jobs. Like benefits, it is not possible to determine an a priori sign on the effect of wages.

We also included two variables related to firm size in our model. We control for firm size using the firm's payroll and include a measure of payroll growth in our empirical specification. The firm's payroll is the appropriate measure of firm size in British Columbia because firms are classified on the basis of their payroll. The a priori effect of payroll size on claim rates is indeterminate for a number of reasons. First, it is possible that there are economies of scale in accident prevention or claims management behaviour such that larger employers will secure a greater return for each dollar spent than similarly situated smaller firms. Second, to the extent that larger firms make greater investments in human capital, it might be expected that they will more zealously defend that investment by making correspondingly greater investments in accident prevention than smaller employers. On the other hand, since larger firms are more likely to be unionized than smaller firms, we can expect that workers in large firms will have a better understanding of their rights under the law and will be less fearful of employer retaliation if they should file a workers' compensation claim, which suggests there should be more claims filed in these large unionized firms (Hirsch, MacPherson and Dumond, 1997). Consequently, the effect of payrolls, our control for firm size, is indeterminate. We entered payroll as a quadratic in our models because some previous research has found some evidence of nonlinearity in the relationship between payrolls and claim rates.

Payroll growth may also affect the claims rate. As firms hire new employees, the number of young and inexperienced workers increases proportionally. To the extent that these workers may be more likely to be injured at work, then the claims rate should similarly increase. As the firm's workforce contracts, seniority systems are likely to reverse this process, so that workers with less tenure will be laid off, reducing the proportion of less experienced workers. For these reasons, payroll growth should be positively related to the claims rate. On the other hand, older workers recover less quickly from the effects of injury and are more likely to suffer permanent consequences, so that we would expect that payroll growth would differentially affect the long-term disability claims rate. 
Finally, the annual provincial unemployment rate by NAICS (North American Industry Classification System) industry sector for prime age males (25 to 54) was included to capture the effects of general economic activity. We matched the firms in our data to 16 NAICS industry sectors. The unemployment rate was entered in the model by taking the difference between the level of the unemployment rate in each sector and its average during the study period. As the economy expands, firms will book more orders and, consequently, hire more workers, work longer hours, and work more intensively during those hours. At a micro level, workers might have an incentive to file claims if they anticipate a layoff or a deterioration in economic conditions (Fortin and Lanoie, 1992). This may be particularly true for injuries that occurred with a previous employer in British Columbia.

In addition to the claims rate analysis, we also estimate average cost per claim regressions for each claim type as well as regressions for the average duration of short-term disability claims. Fixed effects Generalized Least Squares (GLS) regression procedures were used for these analyses. We include the same independent variables as in the claims rate equations and, in general, expect the same directional relationships.

Table 1 reports the means and standard deviations of the dependent and explanatory variables used in these regressions. There were 126 claims per year for every 1,000 workers in our sample. Of the non-fatal claims, the most common was for short-term disability (64.4 per 1,000 workers), followed by health care only claims (60.5 per 1,000 workers), and longterm disability claims (1.3 per 1,000 workers). Long-term disability claims were by far the most expensive, averaging $\$ 30,071$ per claim. Short-term disability claims averaged $\$ 1,807$ and the mean health care only claim cost $\$ 83$. The overall average cost of a claim was $\$ 1,381$. The average worker in our sample received benefits of $\$ 303.08$ per week, and received short-term disability benefits for 23.5 days. The average firm paid a weekly wage of $\$ 419$, had a payroll of $\$ 1,605,611$ and experienced payroll growth of about 8.9 percent per year.

Figure 1 shows average annual total, health care only and shortterm disability claim rates for the firms in our sample, relative to initial participation in ERA. The data have been normalized by the firm's claims rate during the initial year of participation (i.e., at time 0 ), so that all claims rates are equal to 100. For example, the far left-most data points depict claims rates two years prior to ERA implementation, while the right-handmost data points show the claims rates five years after the introduction of ERA.

These data suggest that the total claims rate as well as the HCO and STD claims rates were higher in the period prior to the implementation of 
TABLE 1

Variable Means and Standard Deviations (Firm Level Data)

\begin{tabular}{lcc}
\hline Variable Name & Mean & $\begin{array}{c}\text { Standard } \\
\text { Deviation }\end{array}$ \\
\hline Participation & 0.677 & 0.468 \\
Weekly benefit & 303.08 & 54.60 \\
Wage & 418.94 & 102.30 \\
Payroll ('000) & $1,605.61$ & $9,924.68$ \\
Payroll growth & 0.089 & 0.202 \\
Unemployment Rate Variable (deviation of prime & & \\
age unemployment rate for prime males by NAICS & $-5.4 \mathrm{E}-5$ & 2.42 \\
sector from historical mean for sector) & & \\
Unemployment Rate by NAICS sector & 9.57 & 2.42 \\
Total claims rate & 126.15 & 168.01 \\
Health care only claims rate & 60.45 & 95.14 \\
Short-term disability claims rate & 64.35 & 102.61 \\
Long-term disability claims rate & 1.293 & 8.886 \\
Fatal claims rate & 0.0545 & 1.958 \\
Total cost per claim & 1381.44 & 5622.16 \\
Cost per health care only claim & 83.05 & 112.70 \\
Cost per short-term disability claim & 1806.61 & 3088.95 \\
Cost per long-term disability claim & $30,071.3$ & $50,764.4$ \\
Claim duration (days per claim) & 23.486 & 34.676 \\
\hline
\end{tabular}

ERA than afterward. In particular, the data indicate that the claims rate fell immediately upon the introduction of experience rating. The claims rates for health care only claims rose subsequently — as did the total claims rate - to pre-ERA levels and then fell again after three years. The STD claims rate continued to fall for two years after ERA implementation, and then rose in the third year following initial participation. The STD rate fell once again in the fifth year following ERA implementation.

It is important to note that the WCB does not collect data on firm employment, so that claims rates were calculated using an estimate of firm employment provided by the WCB. The WCB's estimate was derived using average industry wage rates from Statistics Canada as an estimate of firm wage rates. Employment was determined by dividing firm-reported annual assessable payroll by these estimated wage rates. Admittedly, this is a flawed measure of employment and, consequently, the claims rate, so both variables may be measured with some error. The data may also have 


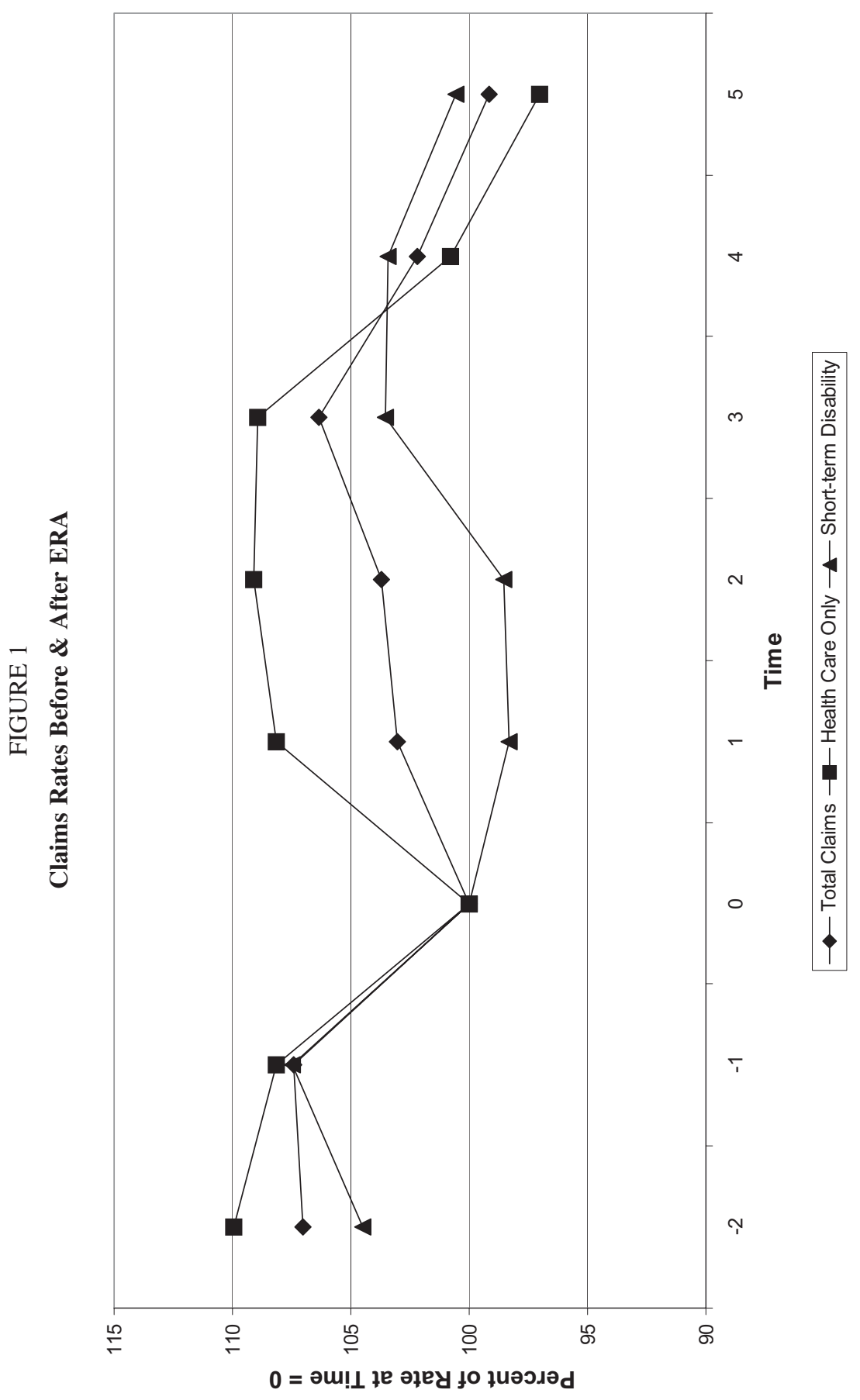


a bias against high-wage employers because the wage data from Statistics Canada are not right-censored, but workers' compensation data on firm payroll are, which will tend to reduce the size of high-wage employers relative to low-wage employers.

Since we had to rely on industry level wages to proxy for firm level wages, within-industry clustering of the errors in our firm-level estimates is likely. The central consequence of this clustering is that the standard errors in the firm-level analysis will be underestimated. ${ }^{8}$ Therefore, we have aggregated our data to the industry level. In the next section, we present results for both the industry-level analysis and the firm-level analysis. We believe that the standard errors from the industry level analysis are more likely to reflect the true statistical significance of our results. As a consequence, we will emphasize the industry-level analyses in the discussion of our results. ${ }^{9}$

\section{RESULTS}

\section{Claims Frequency Analysis Using Industry Level Data}

We estimate the impact of ERA on claims frequencies using a Poisson specification. The parameter estimates for the Poisson model in Table 2a, based on the industry-level data, suggest that participation in ERA has the expected negative effect on total claims-reducing the number of total claims by 8.1 percent. This includes an 8.3 percent reduction in health care only claims, an 8.5 percent reduction in the short-term disability rate, but a 33.3 percent increase in the rate of long-term disability claims. The point estimate from the fatal claims regression is not significantly different from zero at conventional probability levels. The lack of a statistically significant effect of the ERA program on fatal claims may be attributable to two factors. First, there are only a (relatively) small number of fatality claims, so it might be difficult to isolate the effect of ERA on the incidence of these claims. Second, in British Columbia, the fatality claims are assigned to the year the claim is accepted, not when the death is reported. This can lead to measurement problems with fatalities arising from industrial diseases.

8. Wooldridge (2003) discussed how an appropriate adjustment could be made to pooled OLS standard errors when group level information is combined with individual level information. However, we are not aware of any econometric procedures for a similar adjustment in nonlinear models or panel models, akin to our specification.

9. The industry level of aggregation we choose was the "rate group". In British Columbia, rate groups are similar to an industrial classification. The firms in a rate group carry out the same sorts of operations and in British Columbia, are also members of the same industrial classification. 
The claims rate results indicate that participation in ERA affects claim distribution, decreasing the probability of less serious claims (health care only and short-term disability), while increasing the probability of more serious claims. A plausible explanation for this result may be due to the incentives of the ERA program. Recall that under the ERA formula, claim costs, including the capitalized costs of long-term disability pensions, are only included in the calculation of the experience rating adjustment factor if those costs are incurred within the 30-month review period. According to Workers' Compensation Board of British Columbia statistics, less than half of long-term disability benefit costs are assessed in the first three years following the date of injury (i.e., a substantial proportion of workers are not evaluated for their long-term disability benefit until after the 30-month cost review window), suggesting that only a fraction of long-term disability costs are assessed to the individual employer's accident cost record for experience rating purposes. Thus, one interpretation of our results is that the 30-month cost window of ERA creates an incentive for employers to engage in some sort of claims management behaviour in which they dispute long-term disability claims (resulting from injuries that may be difficult to diagnose or attribute to the workplace, such as back injuries and other softtissue and musculoskeletal problems-which can be 40 to 50 percent of claims) and try to mask the incidence of relatively minor health care only and short-term disability claims (i.e., less severe injuries). This is consistent with the observations in Ison (1986) and Kralj (2000), who discuss some of the unintended consequences of experience rating. Specifically, some employers might engage in claims management practices, which involve accommodating workers with some injuries, vigorously protesting and appealing other sorts of injuries, prompt reporting and monitoring the recuperation or rehabilitation process, in an effort to reduce their workers' compensation costs (Thomason and Pozzebon, 2002). In addition, Hyatt and Kralj (1995) found, in their empirical study using data from Ontario, that experience-rated employers were more likely to appeal claims than non-experience-rated employers.

The estimates on the linear benefit term were negative and statistically significant for all the claim types except the long-term disability and fatality claims. The squared benefit variable was positive for all claim types, but not statistically significant in the long-term disability and fatality claims regressions. The difference in the magnitude of the estimates on the linear and squared benefit terms indicates that the linear term, which has a negative sign, will offset the squared term. This suggests that the effect of benefits on firm behaviour (e.g., more investments in safety or increased contesting of claims) dominate the effects on worker behaviour. The wage variable was not statistically significant in any of the regressions. 
The linear term for payroll size was positively related to the incidence of claims in most of the Poisson regression models we estimated in Table $2 \mathrm{a}$, but the squared value of payroll variable was negative. The exception was the health care only regression, in which the pattern was reversed. With the exception of the coefficient on the payroll-squared term in the fatality regression, the estimates on the payroll and its square were statistically significant. However, the estimate on the squared term was quite small, suggesting that a linear relationship between payroll and claims rates dominates. Our estimates imply that as payrolls increase, the total number of claims increases, but at a decreasing rate.

TABLE 2a

Fixed Effect Poisson Model Estimates of Injury Claim Rates, Based on Industry Level Data

\begin{tabular}{|c|c|c|c|c|c|}
\hline & \multicolumn{5}{|c|}{ Claim Type } \\
\hline & $\begin{array}{c}\text { Total } \\
\text { Claims }\end{array}$ & $\begin{array}{c}\text { Health-Care } \\
\text { Only }\end{array}$ & $\begin{array}{l}\text { Short-term } \\
\text { Disability }\end{array}$ & $\begin{array}{l}\text { Long-term } \\
\text { Disability }\end{array}$ & Fatality \\
\hline Participation & $\begin{array}{l}-8.113 * * * \\
(9.98)\end{array}$ & $\begin{array}{l}-8.313 * * * \\
(6.67)\end{array}$ & $\begin{array}{l}-8.546 * * * \\
(7.89)\end{array}$ & $\begin{array}{l}33.317 * * * \\
(4.09)\end{array}$ & $\begin{array}{r}-12.80 \\
(0.25)\end{array}$ \\
\hline Benefits & $\begin{array}{l}-1.203 * * * \\
(8.56)\end{array}$ & $\begin{array}{l}-1.769 * * * \\
(7.97)\end{array}$ & $\begin{array}{l}-0.822 * * * \\
(4.48)\end{array}$ & $\begin{array}{c}-1.546 \\
(1.09)\end{array}$ & $\begin{array}{c}-2.104 \\
(0.26)\end{array}$ \\
\hline Benefits Squared & $\begin{array}{l}0.001 * * * \\
(6.68)\end{array}$ & $\begin{array}{l}0.002^{* * * *} \\
(6.57)\end{array}$ & $\begin{array}{l}0.001 * * * \\
(3.27)\end{array}$ & $\begin{array}{c}0.002 \\
(0.78)\end{array}$ & $\begin{array}{r}0.003 \\
(0.26)\end{array}$ \\
\hline Wages & $\begin{array}{l}-0.008 \\
(0.45)\end{array}$ & $\begin{array}{c}-0.031 \\
(1.07)\end{array}$ & $\begin{array}{c}-0.003 \\
(0.10)\end{array}$ & $\begin{array}{r}0.200 \\
(1.08)\end{array}$ & $\begin{array}{r}0.728 \\
(0.78)\end{array}$ \\
\hline $\begin{array}{l}\text { Payroll } \\
\text { ('000000) }\end{array}$ & $\begin{array}{l}0.012 * * * \\
(2.65)\end{array}$ & $\begin{array}{l}-0.027 * * * \\
(3.96)\end{array}$ & $\begin{array}{l}0.036^{* * *} \\
(6.19)\end{array}$ & $\begin{array}{l}0.122 * * * \\
(2.93)\end{array}$ & $\begin{array}{l}0.762 * * \\
(2.09)\end{array}$ \\
\hline Payroll Squared & $\begin{array}{l}-2.0 \mathrm{E}-8^{* * * *} \\
(2.70)\end{array}$ & $\begin{array}{l}3.6 \mathrm{E}-8 * * * \\
(3.06)\end{array}$ & $\begin{array}{l}-5.3 \mathrm{E}-8^{* * * *} \\
(5.31)\end{array}$ & $\begin{array}{l}-2.4 \mathrm{E}-8 * * * \\
(3.35)\end{array}$ & $\begin{array}{l}-9.1 \mathrm{E}-7 \\
(0.47)\end{array}$ \\
\hline Payroll Growth & $\begin{array}{l}6.368 \\
(1.61)\end{array}$ & $\begin{array}{l}14.25^{* *} \\
(2.40)\end{array}$ & $\begin{array}{l}1.088 \\
(0.20)\end{array}$ & $\begin{array}{c}-124.5^{* * * *} \\
(3.59)\end{array}$ & $\begin{array}{l}11.08 \\
(0.07)\end{array}$ \\
\hline $\begin{array}{l}\text { Unemployment } \\
\text { Rate }\end{array}$ & $\begin{array}{l}-0.587 * * * \\
(4.36)\end{array}$ & $\begin{array}{l}-0.784 * * * \\
(3.91)\end{array}$ & $\begin{array}{l}-0.453 * * \\
(2.46)\end{array}$ & $\begin{array}{c}0.399 \\
(0.31)\end{array}$ & $\begin{array}{r}-11.10 \\
(1.31)\end{array}$ \\
\hline
\end{tabular}

Notes: Absolute value of t-statistics in parentheses. * denotes significance at 10 percent level. $* *$ denotes significance at 5 percent level. $* * *$ denotes significance at 1 percent level.

Payroll growth has a positive and statistically significant relationship to the frequency of health care only claims. Notable, however, is the statistically significant but negative estimate on the payroll growth variable in the long-term disability model. These estimates suggest that as payrolls increase and, consequently, employment increases, the incidence of longterm disability claims declines, which is contrary to our expectations. This 
finding may be due to the possibility that, in the face of increased demand, employers may either increase employment or the hours worked by the existing workforce. By increasing employment, firms reduce the probability of a claim by reducing the average burden of each employee. On the other hand, changes in payroll may be a poor proxy for changes in employment because they may also reflect wage increases.

Finally, our parameter estimates for the unemployment rate were negative whenever they were statistically significant (specifically in the total claims, health care only and short-term disability claims regressions). The estimate on the unemployment variable for long-term disability claims had a positive sign, which could be interpreted as suggesting that the more severe injuries may increase during periods of economic contractions. However, this estimate is not statistically significant.

\section{Claims Frequency Analysis Using Firm Level Data}

We also estimated Poisson regression models for the firm level data. These results are presented in Table $2 b$. The coefficients on the participation variable, estimated using the firm level data, are larger for total claims, health care only and short-term disability claims, than are those in Table 2a, based on industry-level data. Based on firm-level data (industrylevel results in brackets), total claims, health care only and short-term disability claims decreased by 21.4 (8.1), 24.4 (8.3) and 20.0 (8.5) percent, respectively, following the introduction of ERA. In addition, the ERA program was associated with a 23.8 percent increase ( 33.3 percent increase) in long-term disability claims. The estimate in the fatality claims regression was not statistically significant using either the firm-level or industry-level data.

Most of the estimates on the other control variables were similar to those in Table 2a. The signs of the effects do not, for the most part, differ between the industry and firm level analyses. However, as with the impact of ERA, the magnitudes differ somewhat. A notable exception is the relationship between payroll size and claims frequency. For the firm-level analyses, the signs of the coefficients on payroll and payroll squared reveal a U-shaped relationship to each of the claims types (though both coefficients are statistically insignificant in the fatal claims regression).

\section{Claim Costs Using Industry Level Data}

Our expectations with respect to benefits and wages are similar to those from the claims incidence analysis. We have no particular expectation with respect to payroll levels, but we hypothesize that payroll growth will be 
TABLE $2 b$

Fixed Effect Poisson Model Estimates of Injury Claim Rates, Based on Firm Level Data

\begin{tabular}{llllll}
\hline & \multicolumn{5}{c}{ Claim Type } \\
\cline { 2 - 6 } & Total Claims & $\begin{array}{c}\text { Health-Care } \\
\text { Only }\end{array}$ & $\begin{array}{c}\text { Short-term } \\
\text { Disability }\end{array}$ & $\begin{array}{c}\text { Long-term } \\
\text { Disability }\end{array}$ & Fatality \\
\hline Participation & $-21.408 * * *$ & $-24.449 * * *$ & $-20.000 * * *$ & $23.867 * * *$ & 7.614 \\
& $(32.24)$ & $(24.02)$ & $(22.59)$ & $(3.57)$ & $(0.17)$ \\
Benefits & $-1.503 * * *$ & $-2.152 * * *$ & $-1.036 * * *$ & -1.183 & $-13.481 * *$ \\
& $(12.60)$ & $(11.37)$ & $(6.66)$ & $(1.00)$ & $(1.98)$ \\
Benefits & $0.002 * * *$ & $0.003 * * *$ & $0.001 * * *$ & 0.001 & $0.017 *$ \\
Squared & $(10.41)$ & $(9.86)$ & $(5.19)$ & $(0.27)$ & $(1.83)$ \\
Wages & $-0.048 * * *$ & $-0.111^{* * *}$ & -0.012 & $0.230 *$ & 0.646 \\
& $(3.23)$ & $(4.79)$ & $(0.58)$ & $(1.70)$ & $(0.91)$ \\
Payroll & $-0.028 * * *$ & $-0.035 * * *$ & $-0.024 * * *$ & $-0.060 * *$ & 0.077 \\
('000000) & $(9.52)$ & $(7.37)$ & $(6.23)$ & $(2.08)$ & $(0.16)$ \\
Payroll & $2.8 \mathrm{E}-10^{* * * *}$ & $2.9 \mathrm{E}-10^{* * * *}$ & $2.8 \mathrm{E}-10^{* * * *}$ & $8.9 \mathrm{E}-10 * *$ & $-2.7 \mathrm{E}-9$ \\
Squared & $(6.76)$ & $(4.70)$ & $(5.06)$ & $(2.19)$ & $(0.47)$ \\
Payroll Growth & -0.859 & 1.734 & -2.004 & $-69.034 * * *$ & -74.465 \\
& $(0.82)$ & $(1.12)$ & $(1.41)$ & $(5.53)$ & $(1.18)$ \\
Unemployment & $-0.387 * * *$ & -2.289 & $-0.534 * * *$ & 0.866 & -2.34 \\
Rate & $(3.21)$ & $(1.28)$ & $(3.24)$ & $(0.78)$ & $(0.35)$ \\
\hline
\end{tabular}

Notes: Absolute value of t-statistics in parentheses. * denotes significance at 10 percent level. $* *$ denotes significance at 5 percent level. $* * *$ denotes significance at 1 percent level.

negatively related to claim costs and days lost, since increased employment will reflect a younger workforce that is less susceptible to the effects of workplace injuries. The provincial unemployment rate by NAICS industrial sector should be positively related to claim costs and days lost because an increase in the unemployment rate reflects a reduction in the opportunity costs of disability.

GLS fixed effects estimates of claims costs based upon industry-level data are reported in the four left-hand-most columns of Table $3 \mathrm{a}$. The participation variable is associated with an increase of \$275.09 in total claim costs, $\$ 41.09$ in health care only claim costs, $\$ 19.47$ in short-term disability costs and \$2,067.79 in long-term disability claim costs. However, only the estimate for the health care only claims was statistically significant. Most of the other explanatory variables were not statistically significant in the industry level analysis. 
TABLE 3a

Fixed Effect Regression Estimates of Average Claim Costs, Based on Industry Level Data

\begin{tabular}{lccccc}
\hline \multicolumn{5}{c}{ Claim Type } & \\
\cline { 2 - 5 } & Total Claims & $\begin{array}{c}\text { Health-Care } \\
\text { Only }\end{array}$ & $\begin{array}{c}\text { Short-term } \\
\text { Disability }\end{array}$ & $\begin{array}{c}\text { Long-term } \\
\text { Disability }\end{array}$ & Duration \\
\hline Participation & 275.09 & $41.09 * * *$ & 19.47 & 2067.79 & 0.668 \\
& $(1.29)$ & $(3.27)$ & $(0.16)$ & $(1.01)$ & $(0.53)$ \\
Benefits & -27.286 & $3.689^{*}$ & -19.062 & 517.64 & 0.125 \\
& $(0.85)$ & $(1.90)$ & $(1.01)$ & $(1.48)$ & $(0.65)$ \\
Benefits Squared & 0.047 & -0.004 & 0.040 & $-0.796^{*}$ & -0.0003 \\
& $(1.08)$ & $(1.49)$ & $(1.56)$ & $(1.66)$ & $(0.12)$ \\
Wages & -0.046 & $-0.800^{* * *}$ & $-4.999^{*}$ & 22.78 & $-0.049^{*}$ \\
& $(0.01)$ & $(3.09)$ & $(1.94)$ & $(0.53)$ & $(1.89)$ \\
Payroll & 271.0 & 5.690 & 208.1 & 639.9 & $3.180^{* *}$ \\
('000000) & $(1.11)$ & $(0.40)$ & $(1.46)$ & $(0.35)$ & $(2.20)$ \\
Payroll Squared & $-4.7 \mathrm{E}-6$ & $-7.8 \mathrm{E}-8$ & $-3.5 \mathrm{E}-6$ & $-8.2 \mathrm{E}-6$ & $-5.3 \mathrm{E}-8 * *$ \\
& $(1.06)$ & $(0.30)$ & $(1.32)$ & $(3.35)$ & $(1.99)$ \\
Payroll Growth & -796.2 & -50.370 & -325.3 & $-19593.4 * * *$ & -6.470 \\
& $(1.08)$ & $(1.17)$ & $(0.73)$ & $(2.70)$ & $(1.44)$ \\
Unemployment & 49.305 & $8.218 * * *$ & $49.803 *$ & -179.89 & $0.605 * *$ \\
Rate & $(1.09)$ & $(3.10)$ & $(1.88)$ & $(0.45)$ & $(2.25)$ \\
\# of observations & 391 & 385 & 387 & 276 & 387 \\
\# of industries & 49 & 49 & 49 & 44 & 49 \\
\hline
\end{tabular}

Notes: Absolute value of t-statistics in parentheses. * denotes significance at 10 percent level. ** denotes significance at 5 percent level. *** denotes significance at 1 percent level.

\section{Claims Costs Using Firm Level Data}

We also estimated our cost regressions using the firm level data, the results of which are presented in the four left-hand-most columns of Table 3b. Sample size varies by claim type, since individual year observations for firms were dropped from the sample if they failed to experience any claims of that type during the year-that is, years in which a firm incurred zero claim costs for a particular type of claim during a specific year were dropped from the sample of observations used to estimate the cost-regression for that claim-type. In other words, we are interested in the effect of ERA on claim costs conditional on the firm having claims. We again include the same independent variables in these regressions as in the claims rate analysis. 
TABLE 3b

Fixed Effect Regression Estimates of Average Claim Costs, Based on Firm Level Data

\begin{tabular}{|c|c|c|c|c|c|}
\hline & \multicolumn{4}{|c|}{ Claim Type } & \multirow[b]{2}{*}{ Duration } \\
\hline & $\begin{array}{c}\text { Total } \\
\text { Claims }\end{array}$ & $\begin{array}{c}\text { Health-Care } \\
\text { Only }\end{array}$ & $\begin{array}{l}\text { Short-term } \\
\text { Disability }\end{array}$ & $\begin{array}{l}\text { Long-term } \\
\text { Disability }\end{array}$ & \\
\hline Participation & $\begin{array}{l}398.72 * * * \\
(32.24)\end{array}$ & $\begin{array}{l}20.44 * * * \\
(7.36)\end{array}$ & $\begin{array}{c}238.58 * * * \\
(3.37)\end{array}$ & $\begin{array}{r}1662.26 \\
(0.32)\end{array}$ & $\begin{array}{l}4.656 \text { *** } \\
(5.72)\end{array}$ \\
\hline Benefits & $\begin{array}{l}-2.132 \\
(0.10)\end{array}$ & $\begin{array}{r}0.362 \\
(0.68)\end{array}$ & $\begin{array}{c}-3.188 \\
(0.24)\end{array}$ & $\begin{array}{l}1372.7 \\
\quad(1.31)\end{array}$ & $\begin{array}{c}0.170 \\
(1.98)\end{array}$ \\
\hline Benefits Squared & $\begin{array}{r}0.006 \\
(0.18)\end{array}$ & $\begin{array}{r}-0.001 \\
(0.79)\end{array}$ & $\begin{array}{r}0.020 \\
(0.99)\end{array}$ & $\begin{array}{l}-2.184 \\
(1.51)\end{array}$ & $\begin{array}{l}-0.0001 \\
(0.54)\end{array}$ \\
\hline Wages & $\begin{array}{l}-0.371 \\
(0.14)\end{array}$ & $\begin{array}{r}0.001 \\
(0.02)\end{array}$ & $\begin{array}{l}-4.175^{* *} \\
(2.52)\end{array}$ & $\begin{array}{r}147.49 \\
(1.41)\end{array}$ & $\begin{array}{l}-0.028 \\
(1.47)\end{array}$ \\
\hline $\begin{array}{l}\text { Payroll } \\
\text { ('000000) }\end{array}$ & $\begin{array}{l}8.070 \\
(0.38)\end{array}$ & $\begin{array}{l}1.040^{* *} \\
(2.29)\end{array}$ & $\begin{array}{l}3.050 \\
(0.26)\end{array}$ & $\begin{array}{c}-0.001 \\
(1.56)\end{array}$ & $\begin{array}{r}0.017 \\
(0.13)\end{array}$ \\
\hline $\begin{array}{l}\text { Payroll Squared } \\
\text { (‘000000) }\end{array}$ & $\begin{array}{l}-4.3 \mathrm{E}-9 \\
(0.12)\end{array}$ & $\begin{array}{l}-1.2 \mathrm{E}-9 \\
(1.53)\end{array}$ & $\begin{array}{l}-2.6 \mathrm{E}-9 \\
(0.13)\end{array}$ & $\begin{array}{l}4.8 \mathrm{E}-7 \\
(1.12)\end{array}$ & $\begin{array}{l}-3.5 \mathrm{E}-12 \\
(0.47)\end{array}$ \\
\hline Payroll Growth & $\begin{array}{c}-500.1 * * * \\
(3.02)\end{array}$ & $\begin{array}{c}-11.30 \text { *** } \\
(2.81)\end{array}$ & $\begin{array}{c}-511.2 * * * \\
(5.05)\end{array}$ & $\begin{array}{l}1225.0 \\
(0.13)\end{array}$ & $\begin{array}{l}-5.011 \\
(4.31)\end{array}$ \\
\hline $\begin{array}{l}\text { Unemployment } \\
\text { Rate }\end{array}$ & $\begin{array}{c}-35.585^{*} \\
(1.74)\end{array}$ & $\begin{array}{r}-0.043 \\
(0.09)\end{array}$ & $\begin{array}{l}-45.37 * * * \\
(3.64)\end{array}$ & $\begin{array}{r}1084.6 \\
\quad(1.23)\end{array}$ & $\begin{array}{c}0.452 \\
(3.16)\end{array}$ \\
\hline \# of observations & 26,158 & 20,930 & 20,354 & 2,094 & 20,547 \\
\hline \# of firms & 4,088 & 3,882 & 3,778 & 999 & 3,779 \\
\hline
\end{tabular}

Notes: Absolute value of t-statistics in parentheses. ${ }^{*}$ denotes significance at 10 percent level. $* *$ denotes significance at 5 percent level. $* * *$ denotes significance at 1 percent level.

The magnitudes and statistical significance of the impact of experience rating differ from the industry-level estimates in Table 3a. In Table 3b, for the firm level data, ERA participation is associated with an increase of $\$ 20.44$ in the average cost of a health care only claim and a $\$ 238.58$ increase in the average cost of a short-term disability claim (both statistically significant). The average cost of a long-term disability claim falls after the introduction of experience rating, but this estimate is not statistically significant. Overall, the cost of the average workers' compensation claim increased by a statistically significant $\$ 398.72$ following experience rating. Taken together with the reduction in claims rates associated with ERA that was reported in the previous section, the cost results suggest that firms reduce the incidence of relatively low cost claims.

The estimate on benefits and the squared value of benefits are not statistically significant. We also found that most of the estimates on wages 
are not statistically significant. The only exception was the estimate on the costs of short-term disability, which was significantly negative. Payroll levels are positively related to claim costs for most claim types, although this relationship is not statistically significant in any of our specifications. On the other hand, payroll growth is negatively related to claim costs for all types of claims, except for long-term disability claims. Finally, our coefficient estimates for the unemployment rate were negative for total, health care only and long-term disability costs, but positive for short-term disability costs. The estimate on the unemployment rate for short-term disability costs was significant at the 1 percent level, while that for total claims was only significant at the 10 percent level.

In general, our findings suggest that the firm level data place an [upward] bias on the impact of ERA on expected claim costs. Moreover, the standard errors in the firm level cost analysis, as well as the claims analysis, may also have a downward bias. This implies that the industry level estimates may be the preferred estimates of the impact of ERA on claim costs and rates in British Columbia.

\section{Claim Duration}

The right hand-most column of Table $3 \mathrm{~b}$ presents fixed effects regression results for the average duration (in days) of short-term disability claims using firm level data, for firms that experienced at least one shortterm disability claim during a particular year. These estimates indicate that the average duration of a short-term disability claim increased by about 4.7 days per claim following the introduction of ERA. This is consistent with our finding that the average cost of short-term disability claims increased after the introduction of ERA, and further suggests that firms reduced the number of relatively low-cost claims. Thus, the remaining short-term disability claims would be those of relatively higher cost (one might think of these as claims arising from relatively more severe injuries). ${ }^{10}$ However, our estimate is much smaller (0.7 days) and not statistically significant when we used the industry level data (see Table 3a).

\section{The Impact of ERA on Workers' Compensation Costs}

Our estimates suggest that ERA is generally associated with a reduction in workers' compensation claims frequency and an increase in the average

10. We estimated regressions rather than hazard models because we only had data on the average number of days lost to work-related injuries for a firm, not the actual number of days for an individual at a firm. 
cost of a claim. ${ }^{11}$ A remaining question is whether the reduction in frequency is sufficient to offset the increases in the average claims cost, thereby reducing workers' compensation system costs?

To address this question, we constructed a new dependent variable - claims cost per 1,000 workers - and re-estimated the cost equations. Table 4a shows the results of this analysis, based upon estimates using industrylevel data. The ERA participation variable is statistically significant in the health care only regression, where the health care costs per 1,000 workers increased by $\$ 4,548$ following the introduction of experience rating. The ERA participation dummy was not statistically significant in any of the total cost regressions for the other claim types.

TABLE $4 \mathrm{a}$

Fixed Effect Regression Estimates of Claim Costs per 1,000 Workers, Based on Industry Level Data

\begin{tabular}{lcccc}
\hline & \multicolumn{4}{c}{ Claim Type } \\
\cline { 2 - 5 } & Total Claims & $\begin{array}{c}\text { Health-Care } \\
\text { Only }\end{array}$ & $\begin{array}{c}\text { Short-term } \\
\text { Disability }\end{array}$ & $\begin{array}{c}\text { Long-term } \\
\text { Disability }\end{array}$ \\
\hline Participation & & $4,548.31^{* * * *}$ & $-28,690$ & $27,492.91$ \\
Benefits & $(0.58)$ & $(2.78)$ & $(1.48)$ & $(1.18)$ \\
& $-9,134.47$ & 413.68 & $-6,547.26 * *$ & $6,106.07$ \\
Benefits Squared & $(1.45)$ & $(1.63)$ & $(2.24)$ & $(1.52)$ \\
& 13.867 & -0.437 & $9.52^{* *}$ & -8.99 \\
Wages & $(1.61)$ & $(1.27)$ & $(2.38)$ & $(1.64)$ \\
& 444.49 & -91.67 & 318.80 & -101.13 \\
Payroll & $(0.45)$ & $(2.72)$ & $(0.79)$ & $(0.21)$ \\
('000000) & 0.068 & -0.000 & 0.036 & -0.007 \\
Payroll Squared & $(1.44)$ & $(0.14)$ & $(1.60)$ & $(0.31)$ \\
& $-1.12 \mathrm{E}-9$ & $-5.06 \mathrm{E}-12$ & $-5.6 \mathrm{E}-10$ & $9.84 \mathrm{E}-11$ \\
Payroll Growth & $(0.15)$ & $(0.15)$ & $(5.31)$ & $(0.26)$ \\
& $-134,821.70$ & -518.16 & $16,779.93$ & $-223,454.90 * * *$ \\
Unemployment & $(0.93)$ & $(0.09)$ & $(0.24)$ & $(2.69)$ \\
Rate & $5,196.73$ & $1.193 .95 * * *$ & $4,607.97$ & 1.296 .36 \\
\hline
\end{tabular}

Notes: Absolute value of t-statistics in parentheses. $*$ denotes significance at 10 percent level. $* *$ denotes significance at 5 percent level. $* * *$ denotes significance at 1 percent level.

The analysis based on the firm-level data, presented in Table $4 \mathrm{~b}$, indicates statistically significant increases in the costs per 1,000 workers

11. On a related note, there has been an increase in health care costs in many jurisdictions. 
of all claims combined, health care only and short-term disability (at the 10 percent level) following the introduction of ERA. Similar to our findings for the average claim cost analysis (Tables $3 a$ and $3 b$ ), the firmlevel data appears to yield a larger impact of ERA on claims costs per 1,000 workers.

TABLE $4 b$

Fixed Effect Regression Estimates of Claim Costs per 1,000 Workers, Based on Firm Level Data

\begin{tabular}{lcccc}
\hline & \multicolumn{4}{c}{ Claim Type } \\
\cline { 2 - 5 } & Total Claims & $\begin{array}{c}\text { Health-Care } \\
\text { Only }\end{array}$ & $\begin{array}{c}\text { Short-term } \\
\text { Disability }\end{array}$ & $\begin{array}{c}\text { Long-term } \\
\text { Disability }\end{array}$ \\
\hline Participation & $41,850.63^{* *}$ & $841.34^{* *}$ & $12,858.62^{*}$ & $41,528.98$ \\
Benefits & $(2.50)$ & $(2.33)$ & $(1.69)$ & $(0.36)$ \\
& $-1,980.14$ & 3.62 & $-3,552.83^{* *}$ & $2,125.57$ \\
Benefits Squared & $(0.63)$ & $(0.05)$ & $(2.47)$ & $(0.09)$ \\
Wages & 3.37 & -0.043 & $6.43^{* * *}$ & -10.79 \\
& $(0.71)$ & $(0.41)$ & $(3.01)$ & $(0.33)$ \\
Payroll & 187.70 & $16.27 * *$ & $374.74 * *$ & $3,038.62$ \\
('000000) & $(0.48)$ & $(1.96)$ & $(2.11)$ & $(1.30)$ \\
Payroll Squared & 0.0006 & $9.41 \mathrm{E}-06$ & 0.0002 & -0.0002 \\
& $(0.19)$ & $(0.16)$ & $(0.12)$ & $(0.04)$ \\
Payroll Growth & $-6.92 \mathrm{E}-13$ & $-1.23 \mathrm{E}-14$ & $-2.1 \mathrm{E}-13$ & $7.63 \mathrm{E}-13$ \\
& $(0.13)$ & $(0.13)$ & $(0.10)$ & $(0.08)$ \\
Unemployment & $-166,261.90^{* * * *}$ & $-2,756.05 * * *$ & $-92,241.20^{* * * *}$ & $-135,661.20 * * *$ \\
Rate & $(6.92)$ & $(5.26)$ & $(8.50)$ & $(0.62)$ \\
\hline
\end{tabular}

Notes: Absolute value of t-statistics in parentheses. * denotes significance at 10 percent level. ** denotes significance at 5 percent level. $* * *$ denotes significance at 1 percent level.

\section{CONCLUSIONS}

In this paper we examined a natural experiment, whereby experience rating of workers' compensation assessments was introduced to a group of employers in British Columbia. The unambiguous results from our study are that experience rating reduced the incidence of claims where only health care interventions were required (but no time was lost from work) and short-term disability claims. Evidence from the analyses based on firm-level data suggests that per claim costs increased following the introduction of experience rating, indicating that experience rating may have its greatest impact on reducing relatively less severe claims (at least 
as measured by the cost of the claim). However, this result is not robust when the data are aggregated to the industry level. Therefore, we cannot be confident regarding the impact of experience rating on average claims costs from our study.

We summarize our key findings as follows:

- The introduction of experience rating resulted in a reduction in the frequency of the total claims rate, and among the claim types, in a reduction in the frequency of health care only and short-term disability claims.

- There is no evidence that experience rating reduced the frequency of fatal injury claims.

- Long-term disability claims frequency increased after the introduction of experience rating.

- There is no evidence that experience rating influences the duration of absences from work.

- Average costs per claim, and per 1,000 for health care only claims, increased after the introduction of experience rating, but we did not obtain any statistically significant estimates (from our preferred analysis) that the costs associated with other claim types changed after the introduction of the program.

It would appear that even very modest financial incentives, such as those in British Columbia, can result in a reduction in claims, at least for relatively minor injuries. However, our study does not allow us to attribute this reduction in claims frequency to investments in health and safety or claims management behaviour.

\section{【 REFERENCES}

BodEn, Leslie I. 1995. "Creating Economic Incentives: Lessons from Workers' Compensation Systems." Proceedings of the Forty-Seventh Annual Meeting of the Industrial Relations Research Association. Madison: IRRA, 282-289.

BRucE, Christopher J. and Frank J. AtKins. 1993. "Efficiency Effects of Premium-Setting Regimes Under Workers' Compensation: Canada and the United States." Journal of Labor Economics, 11 (1, part 2), S38-S69.

ButLER, Richard J. and John D. WorRALL. 1988. "Labor Market Theory and the Distribution of Workers' Compensation Losses." Workers' Compensation Insurance Pricing. D. Appel and P.S. Borba, eds. Boston: Kluwer Academic Publishers, 19-34.

Chelius, James R. and Robert S. Smith. 1983. "Experience-Rating and Injury Prevention." Safety and the Work Force. J. D. Worrall, ed. Ithaca: ILR Press, 128-137. 
Chelius, James R. and Karen Kavanaugh. 1988. "Workers' Compensation and the Level of Occupational Injuries." Journal of Risk and Insurance, 55 (2), 315-323.

Durbin, David and Richard J. ButLer. 1998. "Prevention of Disability from Work-Related Sources." New Approaches to Disability in the Workplace. T. Thomason, J. F. Burton, Jr., and D. Hyatt, eds. Madison: IRRA, 63-86.

Fortin, Bernard and Paul LANOIE. 1992. "Substitution Between Unemployment Insurance and Workers' Compensation." Journal of Public Economics, 49 (3), 287-312.

Harrington, Scott E. 1988. “The Relationship between Standard Premium Loss Ratios and Firm Size in Workers' Compensation Insurance." Workers' Compensation Insurance Pricing. D. Appel and P.S. Borba, eds. Boston: Kluwer Academic Publishers, 95-108.

Hirsch, Barry T., David A. MacPherson, and J. Michael Dumond. 1997. "Workers' Compensation Recipiency in Union and Nonunion Workplaces." Industrial and Labor Relations Review, 50 (2), 213-236.

Hunt, H. Allan. 1992. Workers' Compensation Board of British Columbia Assessment Department Administrative Inventory. Kalamazoo: W.E. Upjohn Institute for Employment Research.

HyatT, Douglas and Boris KRALJ. 1995. "The Impact of Workers' Compensation Experience Rating on Employer Appeals Activity." Industrial Relations, 34 (1), 95-106.

Ison, Terrance B. 1986. "The Significance of Experience Rating." Osgoode Hall Law Journal, 24 (3), 723-742.

KrALJ, Boris. 1995. 'Experience Rating of Workers' Compensation Insurance Premiums and the Duration of Workplace Injuries." Research in Canadian Workers' Compensation. T. Thomason and R. P. Chaykowski, eds. Kingston: IRC Press, 106-122.

KRALJ, Boris. 2000. "Occupational Health and Safety: Effectiveness of Economic and Regulatory Mechanisms." Workers' Compensation: Foundations for Reform. M. Gunderson and D. Hyatt, eds. Toronto: University of Toronto Press, 187-218.

Krueger, Alan B. 1990. "Workers' Compensation Insurance and the Duration of Workplace Injuries." Working Paper no. 3253, National Bureau of Economic Research, Cambridge, Massachusetts.

Moore, Michael J. and W. Kip VISCUSI. 1989. "Promoting Safety through Workers' Compensation: The Efficacy and Net Wage Costs of Injury Insurance." Rand Journal of Economics, 20 (4), 499-515.

RusER, John W. 1985. “Workers' Compensation Insurance, Experience-Rating, and Occupational Injuries.” Rand Journal of Economics, 16 (4), 487-503.

RusER, John W. 1991. "Workers' Compensation and Occupation Injuries and Illnesses." Journal of Labor Economics, 9 (4), 325-350.

Ruser, John W. 1993. "Workers' Compensation and the Distribution of Occupational Injuries.” Journal of Human Resources, 28 (3), 594-617. 
RuSSELL, Louise B. 1974. "Safety Incentives in Workmen's Compensation." Journal of Human Resources, 9 (3), 361-375.

SMITH, Robert S. 1992. "Have OSHA and Workers' Compensation Made the Workplace Safer?" Research Frontiers in Industrial Relations and Human Resources. Madison: IRRA, 557-586.

Thomason, Terry. 1993. "Permanent Partial Disability in Workers' Compensation: Probability and Costs." Journal of Risk and Insurance, 70 (4), 570-590.

Thomason, Terry and Silvanna Pozzebon. 2002. "Determinants of Firm Workplace Health and Safety and Claims Management Practices." Industrial and Labor Relations Review, 55 (2), 286-307.

Thomason, Terry, Timothy P. Schmidle and John F. Burton, Jr. 2001. Workers' Compensation: Benefits, Costs, and Safety under Alternative Insurance Arrangements. Kalamazoo: Upjohn Institute for Employment Research.

Wooldridge, Jeffrey. 2003. "Cluster Sample Methods in Applied Econometrics." American Economic Review, 93 (2), 133-138.

WORKERS' COMPENSATION BOARD OF BRITISH COLUMBIA. 1997. “Classification and Experience Rating." Policy and Regulation Development Bureau, Royal Commission Briefing Paper.

Worrall, John D. and Richard J. Butler. 1988. "Experience Rating Matters." Workers' Compensation Insurance Pricing. D. Appel and P. S. Borba, eds. Boston: Kluwer Academic Publishers, 81-94.

\section{RÉSUMÉ}

\section{La tarification par incidence, les accidents du travail et le coût des prestations : quelques données récentes}

L'indemnisation des travailleurs victimes d'une maladie professionnelle ou d'un accident du travail est un régime d'assurance sociale qui couvre les soins médicaux, la réhabilitation professionnelle et les prestations en espèces. Elle prévoit également des prestations en espèces pour les familles des travailleurs décédés au travail. Semblables à d'autres programmes gouvernementaux d'assurance sociale, ces prestations sont financées par une taxe prélevée sur la liste de paie de l'employeur. Cependant, contrairement à d'autres programmes, le taux retenu varie d'un employeur à l'autre en fonction étroite des coûts encourus par les réclamations.

L'appréciation du taux de cotisation des employeurs à l'assurance obéit à un processus qui se déroule en deux étapes. D'abord, l'entreprise est placée 
dans un taux de groupe, qui reflète les risques sous-jacents d'accident, de sorte que les entreprises qui présentent des risques semblables sont cotisées selon le taux d'un même groupe. Les taux de groupes sont habituellement basés sur le secteur industriel, reflétant ainsi la croyance à l'effet que les salariés d'un même secteur sont exposés aux mêmes risques. Un taux de «base » ou «manuel » est établi pour chaque groupe selon l'historique des réclamations collectives de toutes les entreprises qui appartiennent à ce groupe. Plus précisément, le taux «plancher » est fonction de l'historique des coûts des réclamations récentes de l'ensemble du secteur. Ensuite, le taux de base se voit modifié selon l'historique d'accident d'une entreprise particulière. Les entreprises qui présentent une « situation désastreuse » vont payer un taux proportionnellement plus élevé que le taux plancher, alors que les entreprises qui présentent un dossier favorable vont payer un taux plus bas. Ces ajustements renvoient à ce qui est connu sous l'expression de tarification par incidence et on les retrouve couramment dans bien des régimes d'assurance.

En associant plus étroitement les évaluations de prime aux coûts des réclamations, la tarification par incidence crée une incitation financière à améliorer les conditions de santé et de sécurité sur les lieux de travail et elle se présente maintenant comme la pierre angulaire de la législation en matière de santé et de sécurité au travail en Amérique du Nord. Comme une autre possibilité, la tarification par incidence peut aussi intensifier les incitations à réduire les coûts des réclamations par le biais d'un type de comportement quant à la gestion des réclamations, qui se traduit par le fait que les employeurs ont recours à d'autres moyens (au lieu d'investir dans la santé et la sécurité) de réduire la fréquence et les coûts des réclamations.

Des recherches, qui ont tenté d'évaluer l'effet de la tarification par incidence sur la fréquence et les coûts des accidents du travail, ne démontrent pas de façon constante qu'une réduction des taux de réclamation ou des coûts sont associés à cette forme de tarification. Plusieurs études antérieures portant sur la tarification par incidence ont rencontré des difficultés au plan de la cueillette de données, incluant l'absence de mesures directes de l'évaluation de la tarification, de données à l'échelle de l'entreprise et de trop petits échantillons. Ces difficultés viennent miner la confiance que les chercheurs et les législateurs peuvent accorder aux conclusions des recherches existantes.

Cet essai évalue l'effet de l'introduction de la tarification par incidence en matière d'indemnisation sur les employeurs en Colombie-Britannique en recourant à des données longitudinales. Notre ensemble de données mesure les fréquences et les coûts des réclamations avant et après l'introduction du nouveau programme de tarification et nous permet de rendre compte de l'impact d'autres facteurs qui peuvent influencer les taux et les coûts des réclamations dans le temps. 
Les données utilisées ici proviennent d'un dossier créé par la Commission des accidents du travail de la Colombie-Britannique. Cette base de données des entreprises, pour la période allant de 1983 à 1992 inclusivement, a été construite en utilisant les archives administratives de la Commission des accidents du travail et elle contient de l'information quant au nombre et aux coûts des réclamations par type, quant à la liste de paie imposable, la participation ou non de l'entreprise au programme de tarification par incidence et le taux du groupe auquel l'entreprise appartient. De plus, la Commission a fourni l'information sur le taux de salaire moyen de l'industrie. Quatre types de réclamation ont été évalués : (1) des réclamations où le client n'a pas connu d'invalidité au travail, par conséquent, il n'a reçu que les indemnités en matière de soins de santé ; (2) des réclamations où le demandeur a connu une période de courte invalidité, sans cependant qu'elle soit suivie d'une invalidité permanente ; (3) des réclamations où le demandeur a vécu une incapacité de longue période (permanente); (4) des accidents mortels. Nous avons également considéré le taux global de réclamations. Pour n'importe lequel type de réclamation, le taux représente le nombre annuel d'un type particulier de réclamation par 1000 travailleurs.

Le calcul du taux de réclamation est effectué à l'aide de la version « panel » du modèle de régression de Poisson. En plus de ce calcul, nous avons évalué le coût moyen par réclamation à l'aide des régressions établies pour chaque type de réclamation et nous avons également calculé les régressions pour la durée moyenne des réclamations d'invalidité à court terme. Pour ce genre d'analyse, nous avons eu recours à des procédures de régression de l'ordre des effets fixes des moindres carrés généralisés. Notre variable explicative principale au cœur de ces analyses est une variable nominale qui nous indique le moment où le programme de tarification par incidence est mis en application. Nos modèles incorporent aussi des variables de contrôle pour les salaires et les avantages sociaux hebdomadaires, la liste de paie de l'entreprise, la croissance du volume de cette dernière ; enfin, le taux de chômage dans l'industrie chez les personnes de sexe masculin dans la force de l'âge.

Les conclusions qui se dégagent clairement de notre étude démontrent que la tarification par incidence réduit la fréquence des réclamations dans les cas où seulement des interventions en matière de soins de santé sont requises (mais sans perte de temps au travail) et dans les cas de réclamations pour une invalidité de court terme. Les conclusions quant aux coûts des réclamations ne sont pas aussi évidentes. Les évaluations obtenues à l'aide de notre analyse ne permettent pas d'affirmer que l'introduction de cette tarification a été suivie d'un impact statistiquement significatif sur les coûts de la plupart des réclamations. Cependant, nous avons décelé un accroissement des coûts associés aux réclamations pour les soins de santé. 
Nos conclusions se présentent de la manière suivante : (1) l'introduction de la tarification par incidence s'est traduite par une réduction de la fréquence du taux global de réclamations pour les soins de santé et dans les cas d'invalidité à court terme ; (2) il n'y a aucune preuve à l'effet que la tarification par incidence réduise la fréquence des réclamations dans les cas d'accidents mortels ; (3) les réclamations dans les cas d'invalidité à long terme se sont accrues après l'adoption du programme de tarification ; (4) il n'est pas prouvé que le programme ait un impact sur la durée des absences du travail ; (5) les coûts moyens par réclamation et par 1000 travailleurs n'ont pas été affectés par l'adoption de la tarification par incidence, sauf dans le cas des réclamations pour soins de santé seulement.

En somme, nos calculs indiquent que des incitations d'ordre monétaire très modestes, comme celles qu'on rencontre en Colombie-Britannique, peuvent se traduire par une réduction des réclamations, du moins dans le cas d'accidents relativement mineurs. Cependant, nos observations ne nous permettent pas d'attribuer cette réduction de la fréquence des réclamations à des investissements en santé et en sécurité ou au comportement en matière de gestion des réclamations de la part des entreprises. 